\title{
Species delimitation within the Glaucidium brodiei owlet complex using bioacoustic tools
}

\author{
Chyi Yin Gwee ${ }^{1}$, James A. Eaton ${ }^{2}$, Elize Y. X. $\mathrm{Ng}^{1}$ and Frank E. Rheindt ${ }^{*}$
}

\begin{abstract}
Background: The taxonomy of the Collared Owlet (Glaucidium brodiei) species complex is confused owing to great individual variation in plumage colouration seemingly unrelated to their distribution. Although generally recognised as a single species, vocal differences among the subspecies have been noted by field recordists. However, there is no study assessing the vocal differences among these four subspecies.

Methods: We obtained 76 sound recordings of the G. brodiei species complex comprising all four subspecies. We conducted bioacoustic examinations using principal component analysis and the Isler criterion to quantitatively test species boundaries within the G. brodiei complex. In addition, we compared plumage colouration among 13 specimens of the G. brodiei complex deposited at the Natural History Museum at Tring, UK and the Lee Kong Chian Natural History Museum, Singapore to ascertain the presence of plumage differences across taxa.
\end{abstract}

Results: We found the Bornean and Sumatran populations vocally similar to each other, but distinctly different from the mainland and Taiwan populations. The vocal pattern seems to corroborate plumage distinctions in the colouration of neck collars: the Bornean and Sumatran taxa share a white neck collar, whereas the continental and Taiwan taxa share a rufous neck collar.

Conclusions: We propose the taxonomic elevation of the Sumatran and Bornean populations to species level as Sunda Owlet G. sylvaticum, with one subspecies on Sumatra (G. s. sylvaticum) and Borneo (G. s. borneense) each. Our study corroborates the importance of bioacoustics in ascertaining species boundaries in non-passerines, and emphasises the significance of incorporating multiple species delimitation approaches when making taxonomic decisions.

Keywords: Borneo, Owl, Sumatra, Taxonomy, Vocalisation

\section{Background}

The genus Glaucidium consists mainly of small owl species, which are also known as owlets or pygmy owls. Owing to inter-specific plumage similarities, the taxonomy of this genus is confused, with a variation of 26 to 35 species recognised across different taxonomic treatments. Presently, approximately six species of Glaucidium owlets are recognised across Asia (Ritschard and Schweizer 2007; Dickinson and Remsen 2013; del Hoyo and Collar 2014). Among these, the taxonomic status of the Collared Owlet (G. brodiei) species complex is one of the most debatable among the Old World Glaucidium

\footnotetext{
*Correspondence: dbsrfe@nus.edu.sg

${ }^{1}$ Department of Biological Sciences, National University of Singapore, 16

Science Drive 4, Singapore 117558, Singapore

Full list of author information is available at the end of the article
}

owlets, with a discrepancy in treatments ranging from one (Dickinson and Remsen 2013; del Hoyo and Collar 2014; Gill and Donsker 2017; Clements et al. 2018) to two (Eaton et al. 2016) and possibly three species (Ritschard and Schweizer 2007). The species complex occurs in mostly montane and submontane forest (G. b. brodiei also occurs down to lowlands), and is widespread, with the taxon brodiei occurring from Afghanistan through the Himalayas to Central China and Southeast Asia, sylvaticum from Sumatra, borneense from Borneo and pardalotum from Taiwan Island (Fig. 1). Two other races, tubiger and garoense usually synonymised under the nominate subspecies, although borneense and sylvaticum have also been synonymised by König and Weick (2008).

Discrepancies in the taxonomy of the G. brodiei species complex can be largely attributed to the variation of 


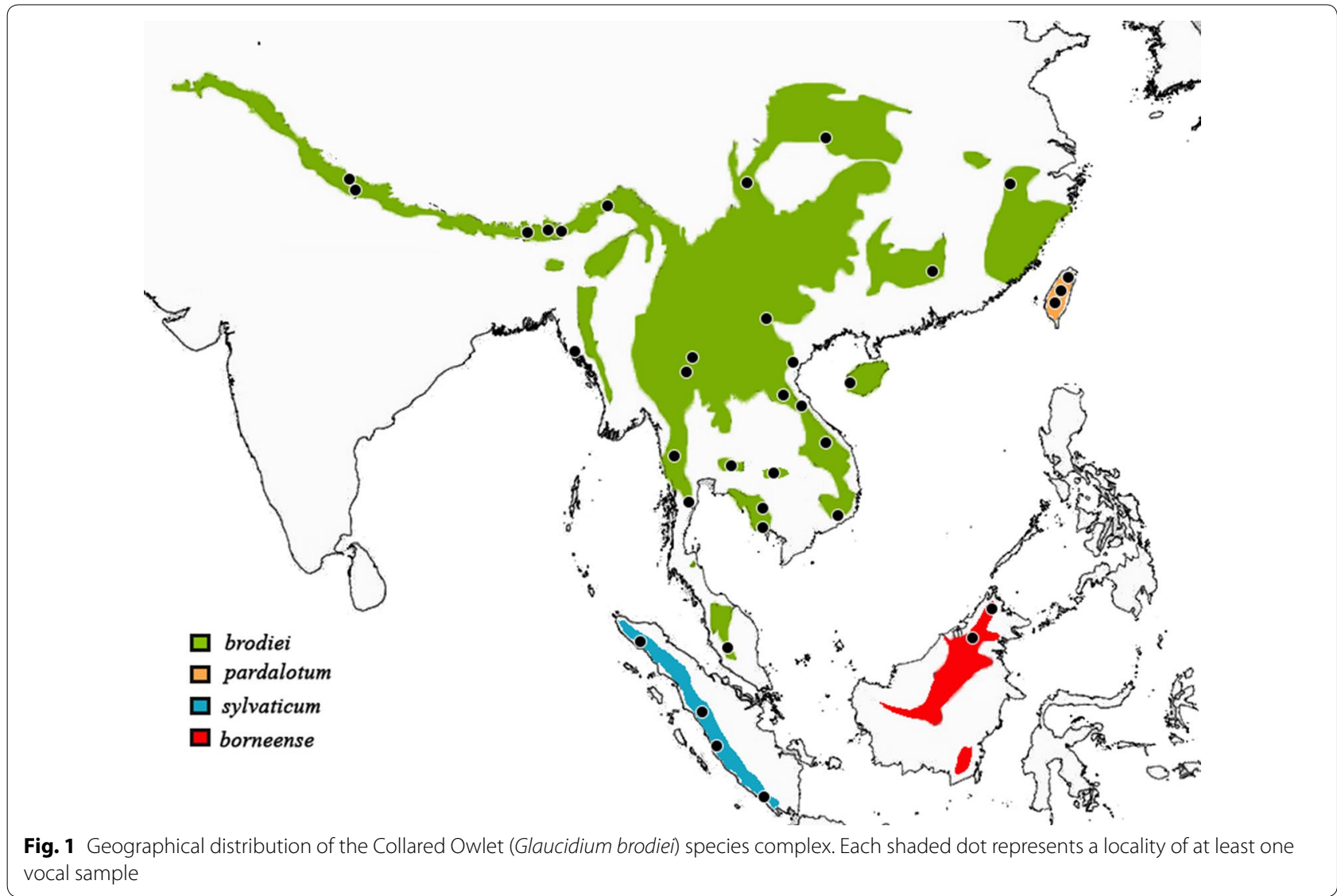

plumage colours observed across individuals unrelated to their distribution (König and Weick 2008). Although these owlets were traditionally thought to exhibit true colour polymorphism (with grey and rufous morphs recognised), a study by Lin et al. (2014) suggests that this intra-specific variation in plumage colours may be agedependent. At any rate, plumage comparison may be an unreliable species delineation tool for this group of owls and other species delimitation methods such as bioacoustics and genetics should be employed to accurately determine species boundaries within the G. brodiei complex. Furthermore, several studies have shown the pitfalls of relying solely on morphology in owl taxonomy, and the importance of bioacoustics in species delimitation of owls is well documented (König 1994; King 2002; Gwee et al. 2017).

Although regarded as a single species, vocal differences within the G. brodiei species complex have been noted by field observers. For example, Eaton et al. (2016) split the Sumatran and Bornean populations as a separate species from other members of the G. brodiei species complex based on notably different vocalisations, though quantitative analysis was unavailable. The pattern of species distribution proposed by Eaton et al. (2016) is quite unusual as both islands have been repeatedly connected to the geographically intervening Malay Peninsula throughout the Pleistocene, suggesting the incidence of a leapfrog pattern (Remsen 1984) in which the terminal taxa sylvaticum and borneense are divided from peninsular brodiei. In the present study, we investigated potential species boundaries among each member of the G. brodiei species complex using bioacoustics as well as plumage comparison of museum specimens. These character suites allowed us to examine species delimitation in the complex in the absence of modern DNA material for the insular populations.

\section{Methods}

\section{Vocal sampling and measurements}

We collected a total of 76 sound recordings of the $G$. brodiei species complex from the online sound library xeno-canto (https://www.xeno-canto.org) and from our personal collection (see Additional file 1: Table S1). In order to avoid duplicate recordings of the same individual, only one out of all the samples recorded by the same person at the same site and time was used for the study. Each sound recording was measured using the default settings on Raven Pro 1.5 (Bioacoustics Research 
Program, Cornell Laboratory of Ornithology, Ithaca, NY, USA). We measured a total of 8 vocal parameters: (1) number of elements per motif, (2) duration of a motif, (3) lowest frequency in a motif, (4) highest frequency in a motif, (5) bandwidth (=highest minus lowest frequency), (6) duration of first break within a motif, (7) duration of second break within a motif, and (8) duration of breaks between motifs. A motif is defined as a complete song that a bird usually repeats several times, while an element is defined as an individual note in the song.

\section{Vocal analyses}

Rstudio version 1.1.453 (https://www.rstudio.com) and R version 3.5.0 ( $\mathrm{R}$ Core Team 2018) were used to conduct principal component analysis (PCA) on the vocal dataset to distinguish clinal bioacoustic variation from discrete variation. Pairwise comparison of each vocal parameter between two taxa were done using the criterion outlined by Isler et al. (1998), henceforth referred to as the Isler criterion. The Isler criterion is based on two conditions: (1) there must be no overlap between the ranges of measurements between the two taxa being compared, and (2) the means $(\bar{x})$ and standard deviations (SD) of the taxon $(t)$ with the smaller set of measurements (a) and the taxon with the larger set of measurements (b) have to meet the following requirement: $\bar{x}_{\mathrm{a}}+t_{\mathrm{a}} \mathrm{SD}_{\mathrm{a}} \leq \bar{x}_{\mathrm{b}}-t_{\mathrm{b}} \mathrm{SD}_{\mathrm{b}}$, where $t_{i}$ refers to the one-tailed $t$-score at the 97.5th percentile of the $t$ distribution for $n-1$ degrees of freedom. Although Isler et al. (1998) first applied this method for the species delimitation of suboscine antbirds, this criterion has also been employed across non-oscines such as pigeons (Rheindt et al. 2011; Ng et al. 2016; Ng and Rheindt,
2016), nightjars (Sangster and Rozendaal 2004), owls (Gwee et al. 2017), as well as oscines (Cros and Rheindt 2017; Prawiradilaga et al. 2017; Gwee et al. 2019).

\section{Plumage and biometric comparisons}

A total of 13 adult specimens, including five mainland brodiei, six Bornean borneense, one Sumatran sylvaticum and one Taiwan pardalotum, were inspected at the Natural History Museum at Tring, UK (NHM Tring) and the Lee Kong Chian Natural History Museum, Singapore (LKCNHM). Photographic evidence of each specimen was taken and relevant plumage traits, such as the colouration of underparts, upperparts and neck collar, were visually assessed across specimens. Additionally, wing and tail measurements of the six specimens from the LKCNHM were obtained by C.Y. Gwee. Given the small sample size, biometric analysis was restricted to a mere comparison of ranges, with no significance testing.

\section{Results}

Spectrograms of song examples from across the G. brodiei species complex reflect the stark vocal differences between populations from Borneo and Sumatra versus populations from mainland Asia and Taiwan (Fig. 2). The vocalisation of Bornean and Sumatran populations comprises seven notes per motif, in contrast to the four notes per motif vocalisation of mainland and Taiwan populations (Fig. 2).

PCA across eight vocal traits confirmed that Bornean borneense and Sumatran sylvaticum populations together form a cluster distinct from continental brodiei and Taiwan pardalotum populations (Fig. 3). This

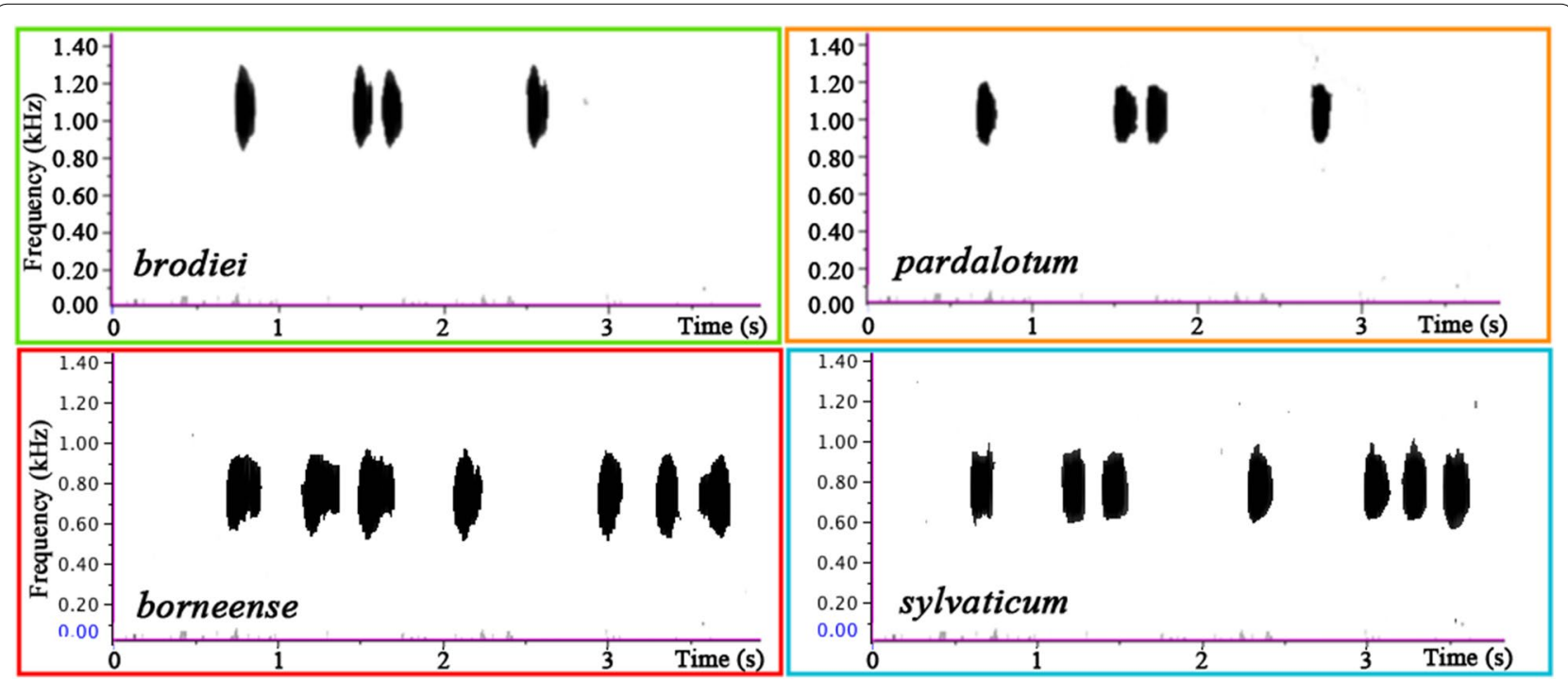

Fig. 2 Spectrograms of the vocalisation of each member of the Glaucidium brodiei species complex 
division was further corroborated by the Isler criterion results which showed at least two diagnosable vocal parameters between the Sundaic insular cluster and the other two taxa (Tables 1,2). On the other hand, Bornean and Sumatran populations were vocally indistinguishable from each other (Fig. 3, Tables 1, 2). The mainland Asian and Taiwan populations were vocally indistinguishable, with large spatial overlap on PCA and an absence of any vocal parameter passing the

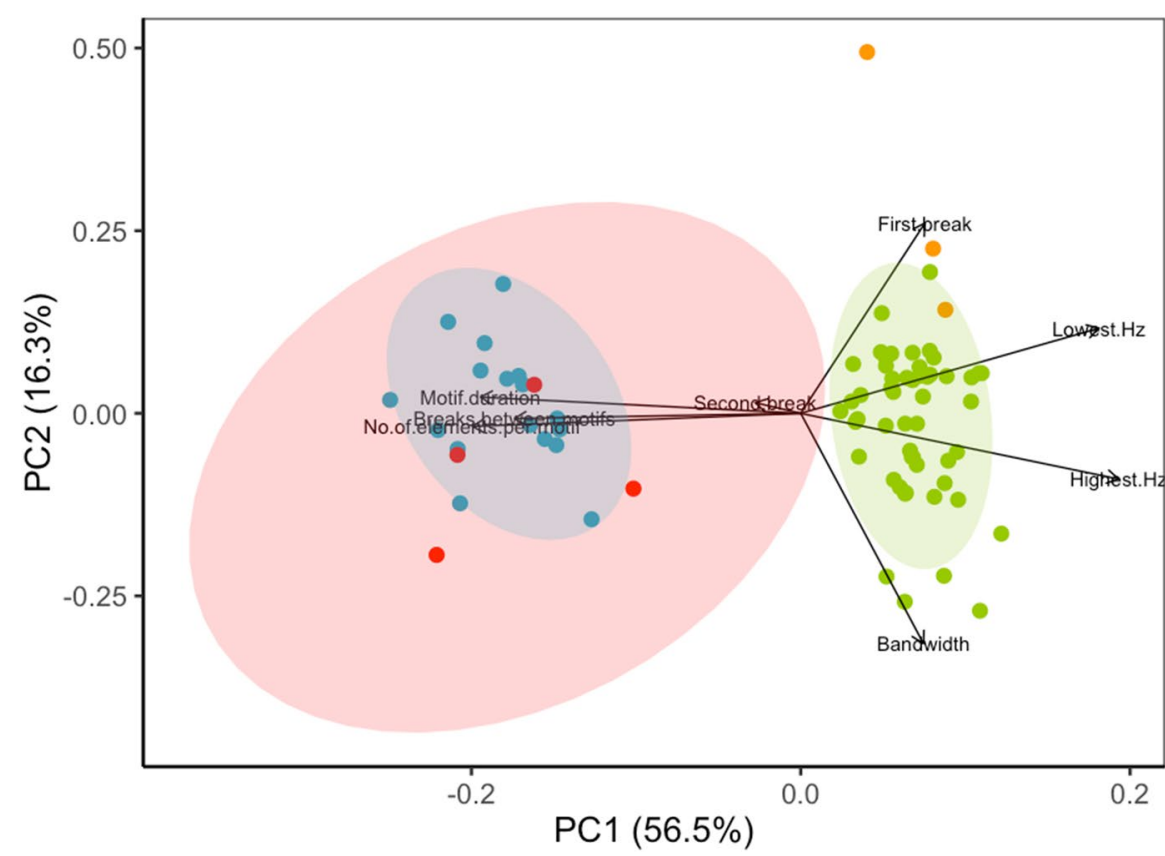

Taxa

- borneense

- brodiei

- pardalotum

- sylvaticum

\begin{tabular}{|lll|}
\hline & \multicolumn{2}{c|}{ Eigenvalues } \\
Parameters & PC1 & PC2 \\
\hline No of element per motif & -0.458 & -0.0410 \\
Motif duration & -0.446 & 0.0510 \\
Lowest $\mathrm{Hz}$ & 0.416 & 0.268 \\
Highest $\mathrm{Hz}$ & 0.443 & -0.206 \\
Bandwidth & 0.171 & -0.723 \\
First break & 0.173 & 0.598 \\
Second break & -0.0634 & 0.0333 \\
Breaks between motifs & -0.399 & -0.0163 \\
\hline
\end{tabular}

Fig. 3 Principal component analysis of eight vocal parameters, with ellipses representing $95 \%$ confidence intervals of the principal component scores for each taxon represented by at least four individuals. The embedded table shows the eigenvalues for each vocal parameter

Table 1 Mean and standard deviation of each vocal parameter across individual taxa

\begin{tabular}{|c|c|c|c|c|c|c|c|c|}
\hline Taxon & a & b & C & d & e & $f$ & g & $\mathbf{h}$ \\
\hline sylvaticum & $7.00 \pm 0.00$ & $3.05 \pm 0.117$ & $618 \pm 39.6$ & $959 \pm 48.1$ & $342 \pm 60.1$ & $0.382 \pm 0.0481$ & $0.115 \pm 0.0158$ & $17.8 \pm 11.8$ \\
\hline borneense & $7.00 \pm 0.00$ & $2.83 \pm 0.0771$ & $614 \pm 26.2$ & $988 \pm 76.8$ & $374 \pm 61.8$ & $0.326 \pm 0.0802$ & $0.149 \pm 0.0432$ & $17.8 \pm 13.8$ \\
\hline brodiei & $3.98 \pm 0.139$ & $1.41 \pm 0.180$ & $806 \pm 53.0$ & $1210 \pm 56.7$ & $400 \pm 63.9$ & $0.415 \pm 0.0553$ & $0.0953 \pm 0.143$ & $0.901 \pm 0.223$ \\
\hline pardalotum & $4.00 \pm 0.00$ & $1.89 \pm 0.00416$ & $879 \pm 42.3$ & $1170 \pm 97.6$ & $290 \pm 140$ & $0.601 \pm 0.0185$ & $0.102 \pm 0.0259$ & $1.95 \pm 0.116$ \\
\hline
\end{tabular}

The following parameters were assessed: (a) number of elements per motif, (b) duration of a motif, (c) lowest frequency, (d) highest frequency, (e) bandwidth, (f) first break length within a motif, $(\mathrm{g})$ second break length within a motif, and $(\mathrm{h})$ break length between motifs

Table 2 List of vocal parameters identified as Isler diagnosable (denoted by ' $X$ ')

\begin{tabular}{|c|c|c|c|c|c|c|c|c|}
\hline & a & b & c & d & e & $f$ & g & h \\
\hline \multicolumn{9}{|l|}{ sylvaticum vs borneense } \\
\hline sylvaticum vs brodiei & $x$ & $x$ & & $x$ & & & & \\
\hline sylvaticum vs pardalotum & $x$ & $x$ & & & & $x$ & & \\
\hline borneense vs brodiei & $x$ & $x$ & $x$ & & & & & \\
\hline borneense vs pardalotum & $x$ & $x$ & & & & & & \\
\hline brodiei vs pardalotum & & & & & & & & \\
\hline
\end{tabular}

The following parameters were assessed: (a) number of elements per motif, (b) duration of a motif, (c) lowest frequency, (d) highest frequency, (e) bandwidth, (f) first break length within a motif, $(\mathrm{g})$ second break length within a motif, and $(\mathrm{h})$ break length between motifs 
threshold of diagnosability under the Isler criterions (Fig. 3, Table 2).

Plumage inspection of the 13 specimens from the NHM Tring and the LKCNHM revealed continental brodiei and

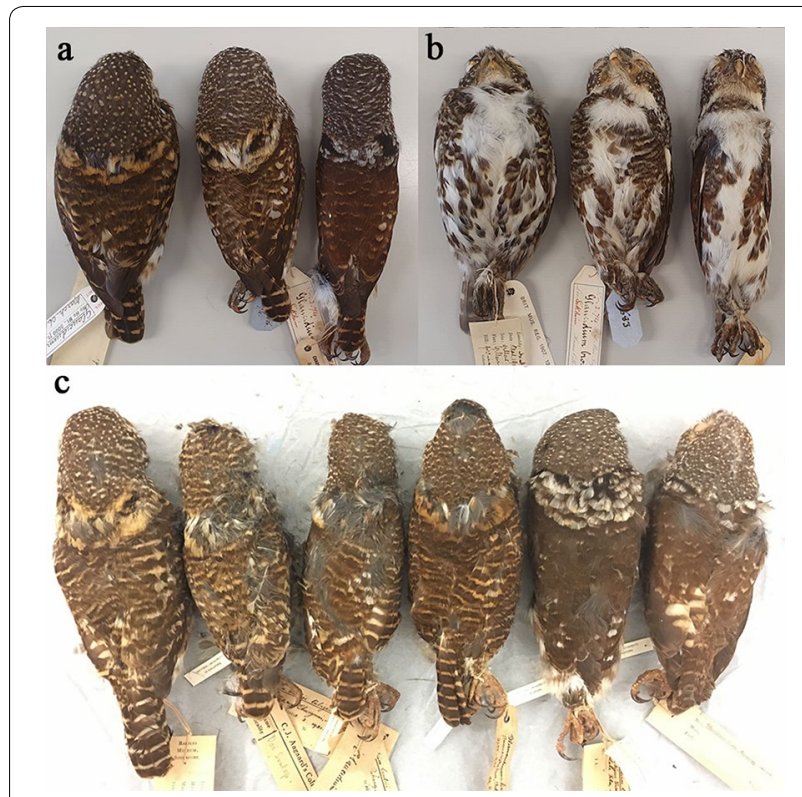

Fig. 4 a Upperparts and $\mathbf{b}$ underparts of pardalotum (1907.12.12.115), brodiei (86.2.1.683) and borneense (93.6.21.1) specimens, respectively, from the Natural History Museum at Tring, UK. c Upperparts of specimens from the Lee Kong Chian Natural History Museum, Singapore. First four specimens from left are brodiei (ZRC3.8606, ZRC3.8607, ZRC3.8610, ZRC3.8612), second from right is sylvaticum (ZRC3.8604) and rightmost is borneense (ZRC3.8603). All specimens show mainland brodiei has a rufous neck collar in contrast to the white neck collar in Sumatran sylvaticum and Bornean borneense
Taiwan pardalotum share a rufous neck collar, whereas Sumatran sylvaticum and Bornean borneense share a while neck collar (Fig. 4, Additional file 2: Fig. S1). Furthermore, biometric comparisons of specimens from the LKCNHM suggest brodiei has a slightly shorter wing (85 to $91 \mathrm{~mm}$ ) than sylvaticum and borneense, though the latter two taxa were represented by only one specimen each (Table 3). On the other hand, the tail measurement of brodiei (44 to $57 \mathrm{~mm}$ ) overlapped with that of borneense $(52 \mathrm{~mm})$. The tail length of the sylvaticum specimen was significantly shorter $(29 \mathrm{~mm})$, possibly due to tail moult. Given small sample sizes, no statistic comparison was attempted on the basis of our biometric measurements.

\section{Discussion}

Vocalisations and plumage agree on two species in the $G$. brodiei complex

The innate vocalisations of owls are an important taxonomic indicator of species limits as they are inherited and subject to strong pressure for mate selection in nocturnal birds (King 2002; Gwee et al. 2017). Our bioacoustic data reflected a stark contrast between the well-known homogenous four-note song separated only by short pauses from other motifs of the Collared Owlet throughout mainland Asia and the seven-note song widely separated from other motifs uttered by insular populations in Sundaland (Fig. 2). Similarly, plumage differences in these owlets, particularly the neck collar colouration, seem to mirror the vocal pattern (Fig. 4). Although Sharpe (1875) commented sylvaticum differs from brodiei by its "rufous brown back", we failed to observe this in specimen ZRC3.8604 (Fig. 4c). Given potential age-related plumage variation in Glaucidium owlets, we caution that such

Table 3 Specimen information and morphometric measurements, if any, of the Glaucidium brodiei complex collection from the Natural History Museum at Tring, UK and the Lee Kong Chian Natural History Museum, Singapore

\begin{tabular}{|c|c|c|c|c|c|}
\hline Taxon & Voucher number & Sex & Locality & $\begin{array}{l}\text { Wing measurement } \\
(\mathrm{mm})\end{array}$ & $\begin{array}{l}\text { Tail } \\
\text { measurement } \\
(\mathrm{mm})\end{array}$ \\
\hline sylvaticum & ZRC3.8604 & Female & Northeast Sumatra, Indonesia & 105 & 29 \\
\hline borneense & ZRC3.8603 & Male & Sarawak, Malaysia & 107 & 52 \\
\hline borneense & 1900.2.14.11 & Male & Sarawak, Malaysia & - & - \\
\hline borneense & 95.11 .15 .57 & Male & Sabah, Malaysia & - & - \\
\hline borneense & 98.11 .24 .62 & Female & Sabah, Malaysia & - & - \\
\hline borneense & 93.6 .22 .3 & Male & Sabah, Malaysia & - & - \\
\hline borneense & 93.6.21.1 & Male & Sarawak, Malaysia & - & - \\
\hline brodiei & ZRC3.8606 & Female & Chiang Mai, Thailand & 91 & 57 \\
\hline brodiei & ZRC3.8607 & Male & Chiang Mai, Thailand & 88 & 50 \\
\hline brodiei & ZRC3.8610 & Male & Pahang, Malaysia & 85 & 44 \\
\hline brodiei & ZRC3.8612 & Female & Pahang, Malaysia & 91 & 53 \\
\hline brodiei & 86.2.1.683 & Male & Sikkim, India & - & - \\
\hline pardalotum & 1907.12 .12 .115 & Male & Mt Ho Ho, Taiwan, China & - & - \\
\hline
\end{tabular}


plumage comparisons should be conservatively regarded (Ritschard and Schweizer 2007; Lin et al. 2014). Our biometric results seem to suggest sylvaticum and borneense have a greater wing length than brodiei regardless of their sex (Table 1). However, the measurements in Sharpe's (1875) record show the wing length of sylvaticum (3.8 in.) and borneense (3.65 in.) overlapped with the female brodiei (3.6 to $3.8 \mathrm{in}$.) which are greater than the male brodiei specimens (3.2 to 3.4 in.). Nevertheless, the distinct vocalisations and consistent neck collar colouration pattern of the Sunda Owlet support an elevation of G. sylvaticum to species status, with the junior Bornean taxon G. s. borneense to be reclassified as a subspecies of G. sylvaticum based on the Principle of Priority (ICZN 1999: Art. 23.1).

\section{Unusual biogeographical divide}

The Isthmus of Kra is a prominent biogeographical and avifaunal divide between northern Southeast Asian monsoon forests and equatorial Sundaic rainforests (Hughes et al. 2003). Numerous Oriental bird species pairs are characterised by a more monsoon-adapted northern and rainforest-adapted southern species that abut somewhere around this transition zone, including owl pairs such as Sunda Scops Owl (Otus lempiji) versus Collared Scops Owl (O. lettia), and Spot-bellied Eagle Owl (Bubo nipalensis) versus Barred Eagle Owl (B. sumatranus). However, in the case of the Collared Owlet complex, the Sundaic population from the Thai-Malay Peninsula is vocally and morphologically undifferentiated from the more northerly monsoon populations, generating an unusual division between continental (Peninsula Malaysia and other parts of mainland Asia) versus archipelagic populations (Sumatra and Borneo). Despite regular linkage through Quaternary land bridges via the geographically intervening Malay Peninsula (Bintanja et al. 2005), the islands of Sumatra and Borneo are known to share multiple montane and submontane species which are absent on the continental mainland. This pattern is observed in the Collared Owlet complex, as well as other avian species such as Rajah's Scops Owl (Otus brookii) and Black-capped White-eye (Zosterops atricapilla).

\section{Differentiation of Taiwan population}

While our bioacoustic data did not support distinct divergence between Taiwan pardalotum and continental brodiei (Tables 1,2), we note that one of the three sound recordings of pardalotum was quite different from continental brodiei (Fig. 3). More samples are required to ascertain whether this vocal difference is clinal as Taiwan forms a continuous landmass with the mainland during the Pleistocene glaciation, or that sample was an anomalous recording. Although the pardalotum specimen seems to have a darker brown upperpart than the brodiei specimens (Fig. 4), intra-specific plumage variation may be present (Ritschard and Schweizer 2007; Lin et al. 2014). Furthermore, Sharpe (1893) found the two taxa to be indistinguishable in plumage during specimen inspection. Therefore, we propose that Taiwan pardalotum be retained as a subspecies of G. brodiei.

\section{Conclusions}

Our study leads to a taxonomic division of an important and well-known Asian owl species complex into two resultant species on the basis of bioacoustic and morphological data. It is therefore one of numerous contributions that highlight the importance of bioacoustics as a tool for species delineation in Strigiformes, which are often challenging to identify by plumage due to age-related or ecomorphological variation (König and Weick 2008; Lin et al. 2014; Mikkola 2014; Sadanandan et al. 2015; Gwee et al. 2017). Modern genetic materials of owl species can be difficult to obtain due to their elusive behaviours and ancient genetic materials can be challenging to work with, thus bioacoustics serve as a reliable tool to scan for cryptic diversity in the absence of genetic data. Future studies can look into using molecular tools to investigate the level of genetic divergence within the G. brodiei species complex, as well as playback experiments to assess species recognition between the Sunda Owlet and Collared Owlet (Freeman and Montgomery 2017). In conclusion, we found vocal evidence further supported by plumage comparisons differentiating the insular Sumatran and Bornean taxa from the mainland and Taiwan taxa. We thereby propose the elevation of G. sylvaticum to species status under the common name Sunda Owlet.

\section{Supplementary information}

Supplementary information accompanies this paper at https://doi. org/10.1186/s40657-019-0175-4.

Additional file 1: Table S1. Information of all recordings used in the study and measurements of all vocal parameters.

Additional file 2: Fig. S1. Photos of all borneense specimens inspected at the Natural History Museum at Tring, UK.

\section{Acknowledgements}

We are indebted to all sound recordists who deposited recordings on XenoCanto (https://www.xeno-canto.org), along with Roger McNeill and Oscar Johnson, both of whom deposited their sound recordings with Macaulay Library (https://www.macaulaylibrary.org) and were kind enough to share their recordings with us.

\section{Authors' contributions}

CYG analysed the vocal data and was the main contributor in writing the manuscript. JAE acquired and measured the sound recordings. EYXN interpreted the results. FER designed the research. All authors read and approved the final manuscript. 


\section{Funding}

This project was funded by the Ministry of Education of the Republic of Singapore (WBS R-154-000-A59-122).

\section{Availability of data and materials}

All data generated or analysed during this study are included in this published article [and its additional information files].

\section{Ethics approval and consent to participate}

Not applicable.

\section{Consent for publication}

Not applicable.

\section{Competing interests}

The authors declare that they have no competing interests.

\section{Author details}

${ }^{1}$ Department of Biological Sciences, National University of Singapore, 16 Science Drive 4, Singapore 117558, Singapore. ${ }^{2}$ A-3A-5, Casa Indah I, Persiaran Surian, 47410 Petaling Jaya, Selangor, Malaysia.

Received: 11 May 2019 Accepted: 10 September 2019

Published online: 17 September 2019

\section{References}

Bintanja R, van de Wal RSW, Oerlemans J. Modelled atmospheric temperatures and global sea levels over the past million years. Nature. 2005;437:125.

Clements JF, Schulenberg TS, Iliff MJ, Roberson D, Fredericks TA, Sullivan BL, et al. The eBird/Clements checklist of birds of the world: v2018; 2018. http://www.birds.cornell.edu/clementschecklist/download/. Accessed 1 Apr 2019.

Cros E, Rheindt FE. Massive bioacoustic analysis suggests introgression across Pleistocene land bridges in Mixornis tit-babblers. J Ornithol. 2017; 158:407-19.

del Hoyo J, Collar NJ. HBW and BirdLife International illustrated checklist of the birds of the world. Non-passerines, vol. 1. Barcelona: Lynx Edicions; 2014

Dickinson EC, Remsen JV Jr. The Howard and Moore complete checklist of the rirds of the world. Non-passerines, vol. 1. Eastbourne: Aves Press; 2013.

Eaton JA, van Balen S, Brickle NW, Rheindt FE. Birds of the Indonesian Archipelago: Greater Sundas and Wallacea. Barcelona: Lynx Edicions; 2016.

Freeman BG, Montgomery GA. Using song playback experiments to measure species recognition between geographically isolated populations: a comparison with acoustic trait analyses. Auk. 2017;134:857-70.

Gill F, Donsker D. IOC World bird names (version 7.1); 2017. http://www.world birdnames.org. Accessed 1 Apr 2019.

Gwee CY, Christidis L, Eaton JA, Norman JA, Trainor CR, Verbelen P, et al. Bioacoustic and multi-locus DNA data of Ninox owls support high incidence of extinction and recolonisation on small, low-lying islands across Wallacea. Mol Phylogenet Evol. 2017;109:246-58.
Gwee CY, Eaton JA, Garg KM, Alström P, van Balen S, Hutchinson RO, et al. Cryptic diversity in Cyornis (Aves: Muscicapidae) jungle-flycatchers flagged by simple bioacoustic approaches. Zool J Linn Soc. 2019;186:725-41.

Hughes JB, Round PD, Woodruff DS. The Indochinese-Sundaic faunal transition at the Isthmus of Kra: an analysis of resident forest bird species distributions. J Biogeogr. 2003;30:569-80.

ICZN (International Commission on Zoological Nomenclature). International code of zoological nomenclature, 4th edn; 1999. http://www.iczn.org/ iczn/index.jsp. Accessed 1 Apr 2019.

Isler ML, Isler PR, Whitney BM. Use of vocalizations to establish species limits in antbirds (Passeriformes: Thamnophilidae). Auk. 1998;115:577-90.

King B. Species limits in the Brown Boobok Ninox scutulata complex. Bull Br Ornithol Club. 2002;122:250-6.

König C. Biological patterns in owl taxonomy, with emphasis on bioacoustical studies on neotropical pygmy (Glaucidium) and screech owls (Otus). In: Chancellor RD, Meyburg BU, editors. Raptor conservation today. London: Pica Press; 1994.

König C, Weick F. Owls of the world. London: Christopher Helm Publishers; 2008.

Lin WL, Lin SM, Tseng HY. Colour morphs in the Collared Pygmy Owl Glaucidium brodiei are age-related, not a polymorphism. Ardea. 2014;102:95-9.

Mikkola H. Owls of the world — a photographic guide. London: A\&C Black; 2014.

Ng NSR, Rheindt FE. Species delimitation in the White-faced Cuckoo-dove (Turacoena manadensis) based on bioacoustic data. Avian Res. 2016;7:2.

$\mathrm{Ng}$ EYX, Eaton JA, Verbelen P, Hutchinson RO, Rheindt FE. Using bioacoustic data to test species limits in an Indo-Pacific island radiation of Macropygia cuckoo doves. Biol J Linn Soc. 2016;118:786-812.

Prawiradilaga DM, Baveja P, Suparno S, Ashari H, Ng NSR, Gwee CY, et al. A colourful new species of Myzomela honeyeater from Rote Island in eastern Indonesia. Treubia. 2017:44:77-100.

R Core Team. R: A language and environment for statistical computing. Vienna: R Foundation for Statistical Computing; 2018. https://www.R-project.org. Accessed 1 Apr 2019.

Remsen JV. High incidence of "leapfrog" pattern of geographic variation in Andean birds: implications for the speciation process. Science. 1984;224:171-3.

Rheindt FE, Eaton JA, Verbelen F. Vocal trait evolution in a geographic leapfrog pattern: speciation in the Maroon-chinned Fruit Dove (Ptilinopus subgularis) complex from Wallacea. Wilson J Ornithol. 2011;123:429-40.

Ritschard M, Schweizer M. Identification of Asian Glaucidium owlets. BirdingASIA. 2007;7:39-47.

Sadanandan KR, Tan DJ, Schjølberg K, Round PD, Rheindt FE. DNA reveals long-distance partial migratory behavior in a cryptic owl lineage. Avian Res. 2015;6:25.

Sangster G, Rozendaal FG. Systematics notes on Asian birds. 41. Territorial songs and species-level taxonomy of nightjars of the Caprimulgus macrurus complex, with the description of a new species. Zool Verh Leiden. 2004;350:7-45.

Sharpe RB. Ordem Strigiformes. Cat Birds Brit Mus 2. 1875;1-325.

Sharpe RB. XLVIII._Bornean notes. Ibis. 1893;5:549-50.
Ready to submit your research? Choose BMC and benefit from:

- fast, convenient online submission

- thorough peer review by experienced researchers in your field

- rapid publication on acceptance

- support for research data, including large and complex data types

- gold Open Access which fosters wider collaboration and increased citations

- maximum visibility for your research: over $100 \mathrm{M}$ website views per year

At BMC, research is always in progress.

Learn more biomedcentral.com/submissions 